\title{
Age and Growth of Blackfin Flounder Glyptocephalus stelleri in the East Sea, Korea
}

\author{
Jae Hyeong Yang ${ }^{1}$, Sang Chul Yoon ${ }^{2 *}$, Sung Il Lee ${ }^{2}$, Hyung Kee Cha ${ }^{3}$, Jong Bin Kim ${ }^{4}$, Young Min Choi ${ }^{1}$ and \\ Jeong Ho Park ${ }^{1}$ \\ ${ }^{1}$ Fisheries Resources and Environment Division, East Sea Fisheries Research Institute, National Fisheries Research and Development \\ Institute, Gangneung, Korea \\ ${ }^{2}$ Fisheries Resources Management Division, National Fisheries Research and Development Institute, Busan, Korea \\ ${ }^{3}$ Subtropical Fisheries Research Center, National Fisheries Research and Development Institute, Jeju, Korea \\ ${ }^{4}$ Fisheries Resources and Environment Division, Southwest Sea Fisheries Research Institute, National Fisheries Research and \\ Development Institute, Yeosu, Korea
}

\begin{abstract}
Age and growth of Glyptocephalus stelleri in the East Sea of Korea were determined, from monthly samples of commercial catches, caught by the eastern sea Danish seine fishery in 2007. The annuli of G. stelleri are formed once a year, with the boundary between opaque and translucent zones forming in September. Relationships between total length (TL) and total weight (TW) were $\mathrm{TW}=0.002 \mathrm{TL}^{3.392}\left(\mathrm{r}^{2}=0.970\right)$ for females and $\mathrm{TW}=0.002 \mathrm{TL}^{3.335}\left(\mathrm{r}^{2}=0.961\right)$ for males. TLs at annuli formation in otoliths were backcalculated from the otolith-length relationship and were adjusted to von Bertalanffy growth curves to $\mathrm{L}_{\mathrm{t}}=39.71\left(1-\exp ^{(-0.152(t+1.156))}\right)$ for females and $\mathrm{L}_{\mathrm{t}}=32.16\left(1-\exp ^{(-0.213(\mathrm{t}+0.879))}\right)$ for males. From the age of 3 yerars, females grew faster than males $(P<0.05)$.
\end{abstract}

Key words: Glyptocephalus stelleri, Blackfin flounder, Age, Growth

\section{Introduction}

Blackfin flounder Glyptocephalus stelleri is distributed in the East Sea and South Sea of Korea, Japan, Sakhalin, Tatar Strait, South Kurils Strait, and Bering Sea (Matarese et al., 1989; Choi et al., 2002). This benthic fish, mostly inhabits depths of more than $300 \mathrm{~m}$ moving to the coast water during its spawning season (Choi et al, 2002; Fedorov et al., 2003; National Fisheries Research and Development Institute, 2004).

G. stelleri are caught by gill nets, longlines, eastern sea Danish seines and bottom trawls in the East Sea, and the catch ratio of this fish reaches up to $54.9 \%$ of the total flounder catches in the East Sea (National Fisheries Research and Development Institute, 2010). Recent increases in the flounder catches are related to increases in the catch of G. stelleri, Recently $G$. stelleri was selected as one of the species for a stock rebuilding project in the East Sea, and research on its ecology has been promoted. There have been many studies on G. stelleri, including studies on its age and growth (Hashimoto, 1953; Ishida and Kitakata, 1953), larvae (Okiyama, 1963), spawning ecology (Ivankova, 1974), feeding (Hayase and Hamai, 1974; Pushchina, 2000), and geographic distribution (Shvydkii and Vdovin, 2001; Tokranov, 2008). Studies of the biology and ecology of $G$. stelleri in Korean waters have included research on growth (Lee, 2008) and reproduction (Cha et al., 2008), and the species has also been reported in wider studies of fish (Park et al., 2007; Yoon et al., 2008; Lee, 2011).
Open Access http://dx.doi.org/10.5657/FAS.2012.0169

This is an Open Access article distributed under the terms of the Creative Commons Attribution Non-Commercial License (http://creativecommons. org/licenses/by-nc/3.0/) which permits unrestricted non-commercial use, distribution, and reproduction in any medium, provided the original work is properly cited. pISSN: 2234-1749 eISSN: 2234-1757
Received 6 January 2012; Revised 10 April 2012

Accepted 28 May 2012

*Corresponding Author

E-mail: yoonsc@nfrdi.go.kr 
Research conducted in Korea on Pleuronectidae species includes studies of the ages and growths of Limanda herzensteini (Choi et al., 1986), Verasper variegatus (Jeon et al., 1996), Pleuronectes yokohamae (Park, 1997)and Kareius bicoloratus (Jun and Im, 2004).

The present study analyzed data on the age and growth of G. stelleri. These results can be used to provide a resource management plan for the continuous exploitation of $G$. stelleri resources.

\section{Materials and Methods}

\section{Fish sampling and data collection}

The G. stelleri samples were caught by the eastern sea Danish seine fishery in the sea adjacent to Gangwon-do, Korea, in 2007 (Fig. 1). Monthly samples were collected from landing ports at Mukho and Sokcho. The fish were sexed and total lengths (TL) and total weight (TW) were maeasured to the nearest $0.1 \mathrm{~cm}$ and $0.1 \mathrm{~g}$, respectively.

\section{Age determination}

A pair of left/right otoliths was extracted and, after the removal of organic matters on the surface, they were dried and treated for easy observation by grinding close to the nucleus with sandpaper. Translucent and opaque zones appeared alternately in the otolith (Fig. 2A). Annuli were found at the boundary between opaque and translucent zones, and these were analyzed on a PC monitor (with the image analyzer package iSolution Lite, IMT i-Solutin Inc., Daejeon, Korea) connected to a dissecting microscope.

The otolith radius $(\mathrm{R})$ was measured along the longest axis from the otolith center to the posterior margin, and the ring radius $\left(r_{n}\right)$ was measured in $\mu \mathrm{m}$ from the otolith center to each annulus (Fig. 2B).

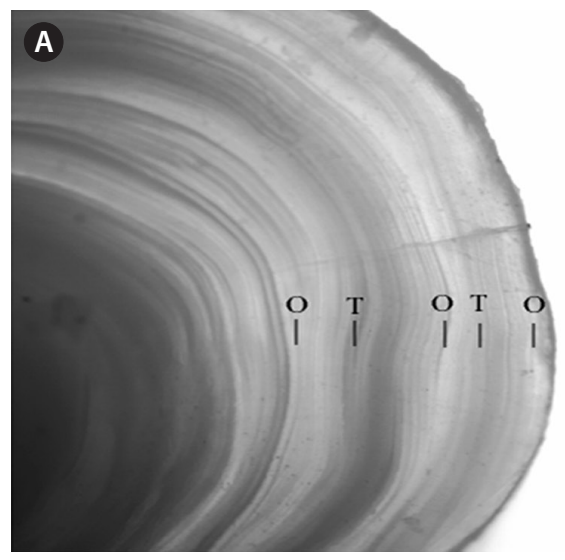

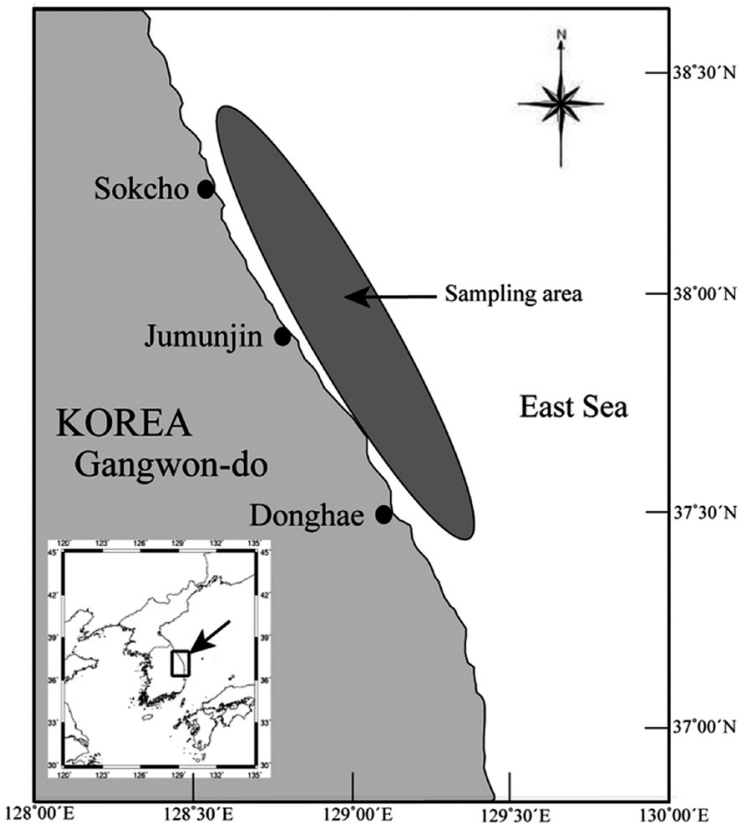

Fig. 1. The sampling area of the Blackfin flounder Glytocephalus stelleri caught by the eastern sea Danish seine in the East Sea.

To determine the period of annulus formation, the monthly variation in the marginal index (MI) was calculated by the following equation:

$$
M I=\frac{R-r_{n}}{r_{n}-r_{n-1}}
$$

$\mathrm{R}$ is otolith radius and $\mathrm{r}_{\mathrm{n}}$ is the ring radius to the $\mathrm{n}-\mathrm{th}$ annulus.

\section{Relationships between TW-TL and TL-R}

Relationship between TW and TL was estimated by $\mathrm{TW}=\mathrm{aTL}{ }^{\mathrm{b}}$, where $\mathrm{a}$ and $\mathrm{b}$ are parameters. Relationship between TL and otolith radius (R) was estimated by linear regression analysis.

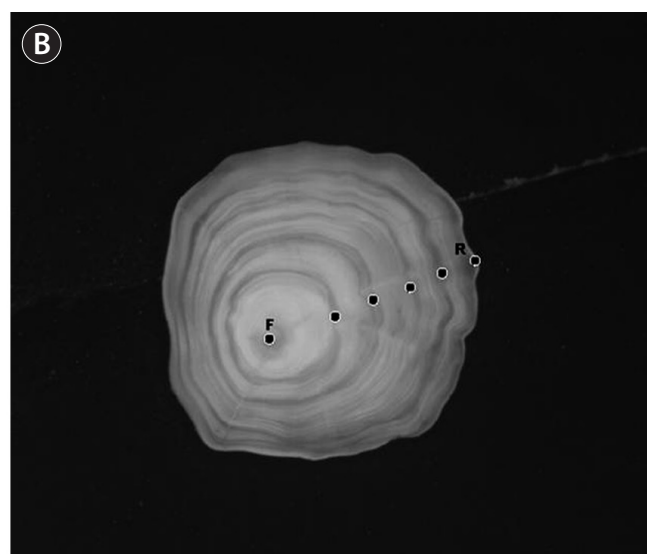

Fig. 2. Otolith of the Blackfin flounder Glyptocephalus stelleri by cutting dimension. (A) Otolith microphotographs of Glyptocephalus stelleri in September (50x, transmitted light; O, opaque zone; T, translucent zone). (B) Count of annual mark (reflected light; $F$, focus; R, radius). 


\section{Growth function}

Growth in length of $G$. stelleri was obtained from the growth function of Von Bertalanffy (1938). The parameters obtained by the Walford method (Walford, 1946) were used as the initial values of the growth formula, which was presumed by nonlinear regression (Microsoft Excel solver routine):

$$
L_{t}=L_{\infty}\left(1-e^{-k\left(t-t_{0}\right)}\right)
$$

$\mathrm{L}_{\mathrm{t}}$ is the TL at age $\mathrm{t}, \mathrm{L}_{\infty}$ is the theoretical maximum length, $\mathrm{K}$ is the growth coefficient, and $\mathrm{t}_{0}$ is the theoretical age at length zero.

\section{Statistical analysis}

An analysis of covariance (ANCOVA) was used to compare weight-length relationships between sexes, and growth difference between males and females for each age was examined by $t$-tests in the SPSS version 12.0 (SPSS INC., Chicago, IL, USA).

\section{Results}

\section{Size composition}

The total number of $G$. stelleri collected in the survey was 6,843 , of which 3,064 were females and 3,779 males. TL was $9.5-38.1 \mathrm{~cm}$ for females and $8.6-29.5 \mathrm{~cm}$ for males, showing that females are longer than males (Fig. 3).

\section{Age determination}

Monthly variation in MI was highest in July, low in August and September, showing an increasing trend from October (Fig. 4). The annuli of G. stelleri were formed from around September at the boundary between opaque and translucent zones in the otolith.

The average ring radius from the otolith center to each annulus is shown in Table 1. It ranged from $r_{1}=1.152 \pm 0.110$ $\mathrm{mm}$ to $\mathrm{r}_{9}=3.782 \pm 0.340 \mathrm{~mm}$ in females and from $\mathrm{r}_{1}=1.160$ $\pm 0.106 \mathrm{~mm}$ to $r_{7}=3.180 \pm 0.098 \mathrm{~mm}$ in males. The average ring radius female was apparently longer than for males, for each age group.

\section{Length-radius and weight-length relationship}

Relationship between $\mathrm{R}$ and TL is shown in Fig. 5. There were significant differences in this relationship between males and females (ANCOVA, $F=5.670, P<0.05$ ), with $\mathrm{TL}=$ $7.901 \mathrm{R}+1.619\left(\mathrm{r}^{2}=0.737\right)$ for females and $\mathrm{TL}=7.892 \mathrm{R}+$ $1.297\left(r^{2}=0.685\right)$ for males.

Relationship between TW and TL is shown in Fig. 6. It was $\mathrm{TW}=0.002 \mathrm{TL}^{3.392}\left(\mathrm{r}^{2}=0.970\right)$ for females and $\mathrm{TW}=$ $0.002 \mathrm{TL}^{3.335}\left(\mathrm{r}^{2}=0.961\right)$ for males.

The average TLs for each annulus were back-calculated from the for going relationship between $\mathrm{R}$ and TL based on the average ring radii to the annuli (Table 2). The estimated TLs of

Table 1. Mean ring radius on the otolith of the Blackfin flounder Glyptocephalus stelleri in the East Sea

\begin{tabular}{|c|c|c|c|c|c|c|c|c|c|c|c|}
\hline \multirow[t]{2}{*}{ Sex } & \multirow{2}{*}{$\begin{array}{c}\text { Estimated } \\
\text { age }\end{array}$} & \multirow{2}{*}{$\begin{array}{c}\text { Number of } \\
\text { samples }\end{array}$} & \multicolumn{9}{|c|}{ Mean otolith ring radius(mm) } \\
\hline & & & $\mathbf{r}_{1}$ & $\mathbf{r}_{2}$ & $\mathbf{r}_{3}$ & $\mathbf{r}_{4}$ & $\mathbf{r}_{5}$ & $\mathbf{r}_{6}$ & $\mathbf{r}_{7}$ & $\mathbf{r}_{8}$ & $\mathbf{r}_{9}$ \\
\hline \multirow[t]{9}{*}{ Female } & 1 & 4 & 1.062 & & & & & & & & \\
\hline & 2 & 12 & 1.136 & 1.689 & & & & & & & \\
\hline & 3 & 76 & 1.171 & 1.765 & 2.176 & & & & & & \\
\hline & 4 & 179 & 1.168 & 1.778 & 2.218 & 2.556 & & & & & \\
\hline & 5 & 110 & 1.153 & 1.736 & 2.176 & 2.538 & 2.820 & & & & \\
\hline & 6 & 39 & 1.077 & 1.673 & 2.133 & 2.503 & 2.816 & 3.060 & & & \\
\hline & 7 & 17 & 1.114 & 1.682 & 2.126 & 2.515 & 2.831 & 3.095 & 3.307 & & \\
\hline & 8 & 4 & 1.152 & 1.681 & 2.111 & 2.490 & 2.829 & 3.141 & 3.409 & 3.576 & \\
\hline & 9 & 3 & 1.090 & 1.621 & 2.068 & 2.454 & 2.779 & 3.080 & 3.346 & 3.579 & 3.782 \\
\hline Weighted mean & & & 1.152 & 1.748 & 2.186 & 2.541 & 2.819 & 3.076 & 3.329 & 3.577 & 3.782 \\
\hline S.D. & & & 0.110 & 0.151 & 0.173 & 0.189 & 0.205 & 0.221 & 0.261 & 0.320 & 0.340 \\
\hline \multirow[t]{7}{*}{ Male } & 1 & 5 & 1.137 & & & & & & & & \\
\hline & 2 & 14 & 1.143 & 1.746 & & & & & & & \\
\hline & 3 & 98 & 1.177 & 1.770 & 2.172 & & & & & & \\
\hline & 4 & 130 & 1.153 & 1.730 & 2.147 & 2.470 & & & & & \\
\hline & 5 & 66 & 1.155 & 1.704 & 2.104 & 2.437 & 2.713 & & & & \\
\hline & 6 & 7 & 1.134 & 1.707 & 2.106 & 2.436 & 2.728 & 2.941 & & & \\
\hline & 7 & 2 & 1.209 & 1.768 & 2.227 & 2.523 & 2.789 & 3.004 & 3.180 & & \\
\hline Weighted mean & & & 1.160 & 1.737 & 2.146 & 2.459 & 2.717 & 2.955 & 3.180 & & \\
\hline S.D. & & & 0.106 & 0.141 & 0.157 & 0.173 & 0.188 & 0.148 & 0.098 & & \\
\hline
\end{tabular}



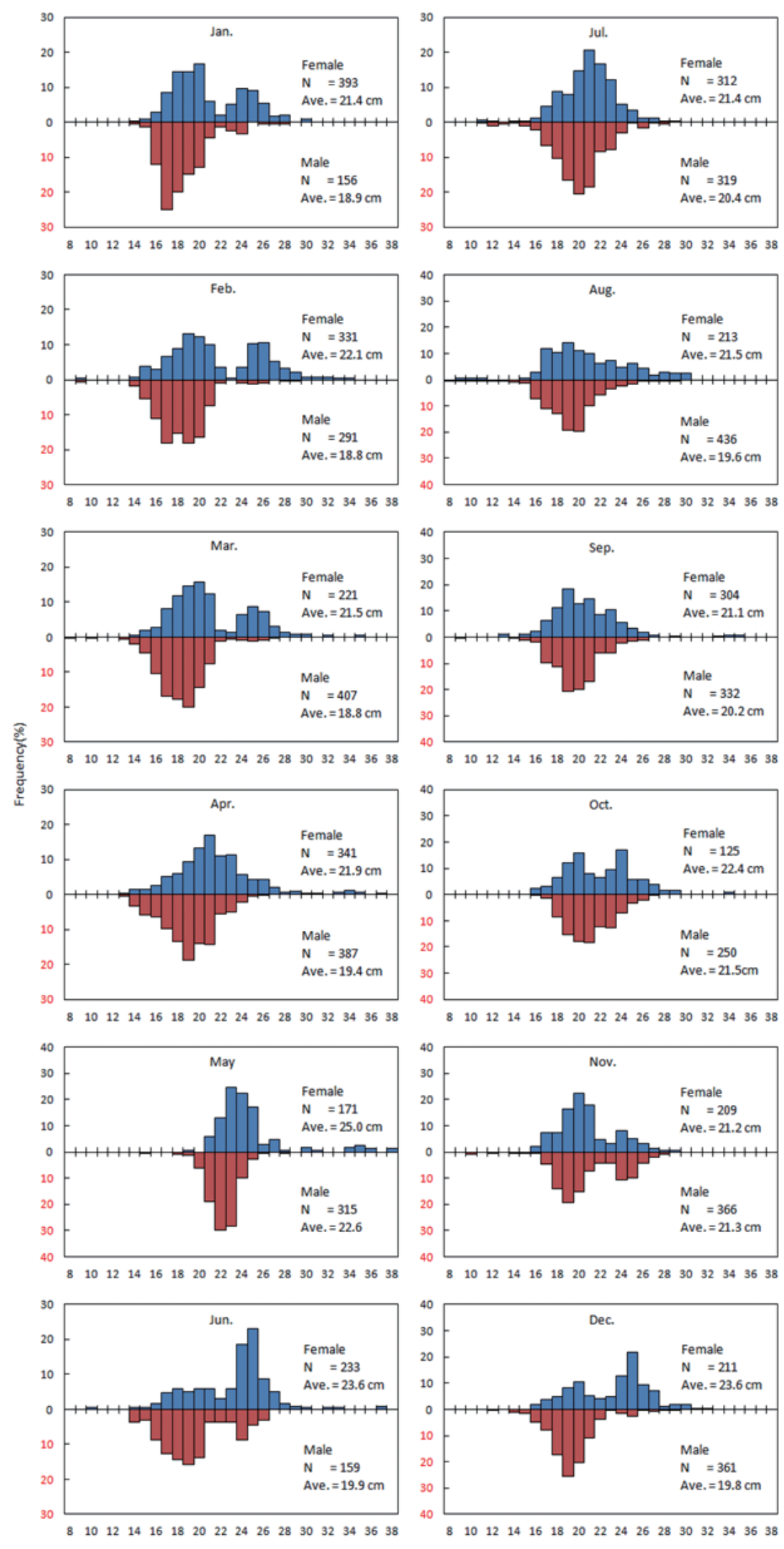

Total length $(\mathrm{cm})$

Fig. 3. Length frequency distribution of the Blackfin flounder Glyptocephalus stelleri in the East Sea from January to December 2007. 


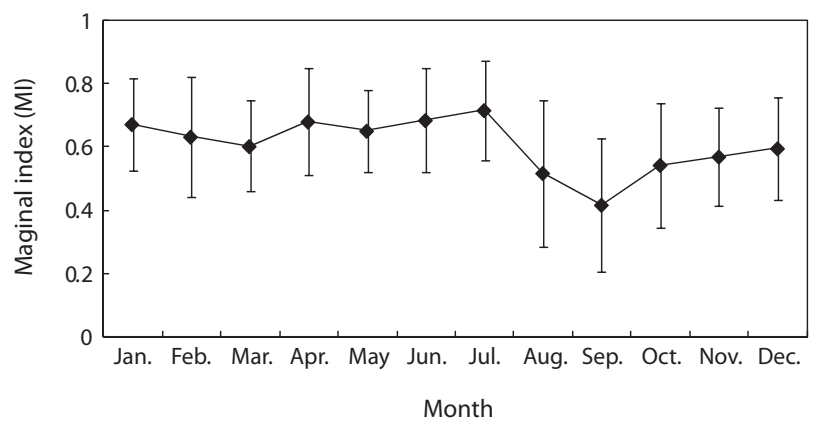

Fig. 4. Monthly changes in marginal index of the Blackfin flounder Glyptocephalus stelleri in the East Sea from January to December 2007.
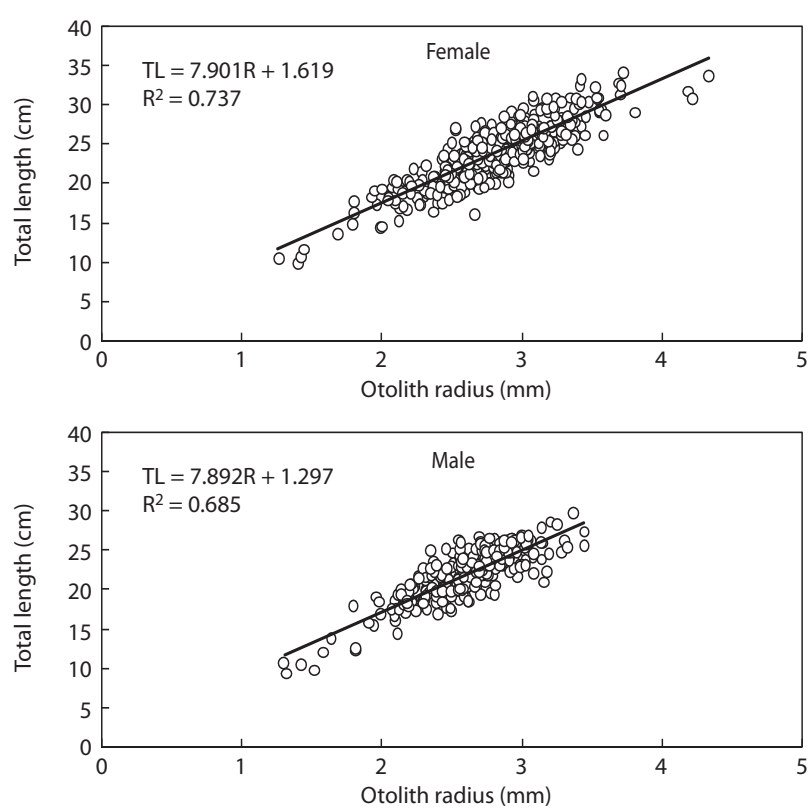

Fig. 5. Relationship between otolith radius and total length of Blackfin flounder Glyptocephalus stelleri in the East Sea from January to December 2007. females were longer than those of males for all ages. The result of $t$-test used examine the growth difference for each age between males and females showed no significant difference from age 1 to $2(\mathrm{P}>0.05)$, but a significant difference from age $3(P<0.05)$. It is assumed that the growth differential between male and female G. stelleri appears from the age of 3.

\section{Growth function}

The Von Bertalanffy growth functions of male and female G. stelleri derived from nonlinear regression analysis, analysis are:
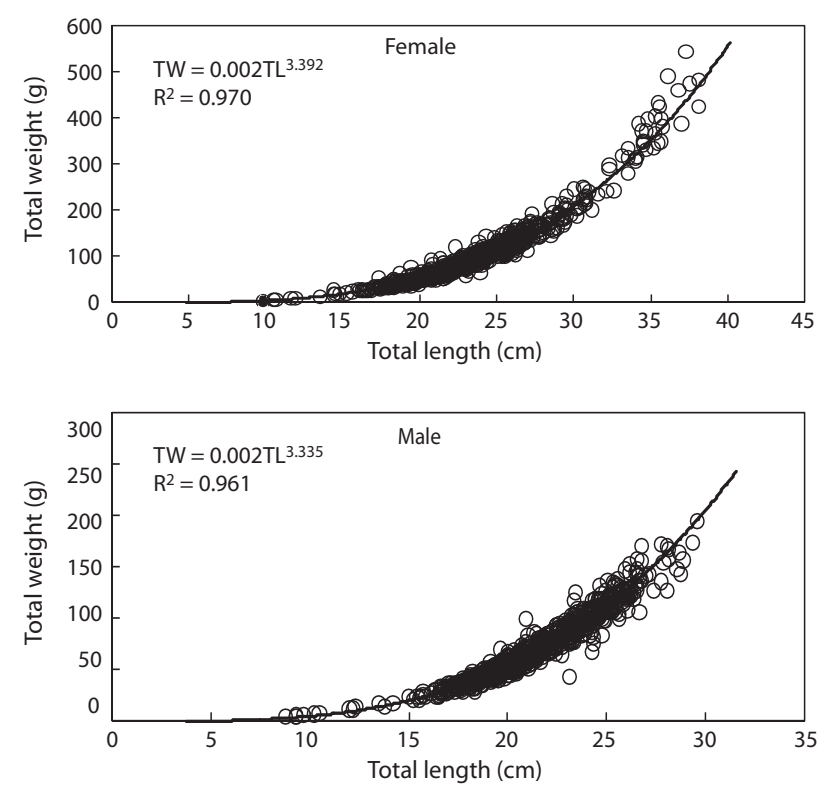

Fig. 6. Relationship between otolith radius and total length of Blackfin flounder Glyptocephalus stelleri in the East Sea from January to December 2007.

Table 2. Back-calculated total length at the formation of annuli in otolith of the Blackin flounder Glyptocephalus stelleri in the East Sea

\begin{tabular}{|c|c|c|c|c|c|c|c|c|c|c|c|}
\hline \multirow{2}{*}{ Sex } & \multirow{2}{*}{$\begin{array}{c}\text { Estimated } \\
\text { age }\end{array}$} & \multirow{2}{*}{$\begin{array}{l}\text { Number of } \\
\text { samples }\end{array}$} & \multicolumn{9}{|c|}{ Mean total length(mm) } \\
\hline & & & $\mathbf{r}_{1}$ & $\mathbf{r}_{2}$ & $\mathbf{r}_{3}$ & $\mathbf{r}_{4}$ & $\mathbf{r}_{5}$ & $\mathbf{r}_{6}$ & $\mathbf{r}_{7}$ & $\mathbf{r}_{8}$ & $\mathbf{r}_{9}$ \\
\hline \multirow[t]{9}{*}{ Female } & 1 & 4 & 10.01 & & & & & & & & \\
\hline & 2 & 12 & 10.59 & 14.97 & & & & & & & \\
\hline & 3 & 76 & 10.87 & 15.56 & 18.81 & & & & & & \\
\hline & 4 & 179 & 10.85 & 15.66 & 19.14 & 21.81 & & & & & \\
\hline & 5 & 110 & 10.73 & 15.33 & 18.81 & 21.67 & 23.90 & & & & \\
\hline & 6 & 39 & 10.13 & 14.84 & 18.47 & 21.39 & 23.87 & 25.80 & & & \\
\hline & 7 & 17 & 10.42 & 14.91 & 18.42 & 21.49 & 23.99 & 26.07 & 27.75 & & \\
\hline & 8 & 4 & 10.72 & 14.90 & 18.30 & 21.29 & 23.97 & 26.43 & 28.55 & 29.87 & \\
\hline & 9 & 3 & 10.23 & 14.43 & 17.95 & 21.01 & 23.57 & 25.95 & 28.06 & 29.90 & 31.50 \\
\hline Weighted mean & & & 10.72 & 15.43 & 18.89 & 21.69 & 23.89 & 25.92 & 27.92 & 29.88 & 31.50 \\
\hline S.D. & & & 0.87 & 1.19 & 1.37 & 1.49 & 1.62 & 1.75 & 2.06 & 2.53 & 2.69 \\
\hline \multirow{7}{*}{ Male } & 1 & 5 & 10.27 & & & & & & & & \\
\hline & 2 & 14 & 10.32 & 15.07 & & & & & & & \\
\hline & 3 & 98 & 10.59 & 15.26 & 18.44 & & & & & & \\
\hline & 4 & 130 & 10.40 & 14.95 & 18.24 & 20.79 & & & & & \\
\hline & 5 & 66 & 10.41 & 14.74 & 17.91 & 20.53 & 22.71 & & & & \\
\hline & 6 & 7 & 10.25 & 14.77 & 17.92 & 20.52 & 22.82 & 24.51 & & & \\
\hline & 7 & 2 & 10.84 & 15.25 & 18.87 & 21.21 & 23.30 & 25.01 & 26.39 & & \\
\hline Weighted mean & & & 10.45 & 15.01 & 18.23 & 20.70 & 22.74 & 24.62 & 26.39 & & \\
\hline S.D. & & & 0.84 & 1.11 & 1.24 & 1.36 & 1.49 & 1.17 & 0.78 & & \\
\hline
\end{tabular}




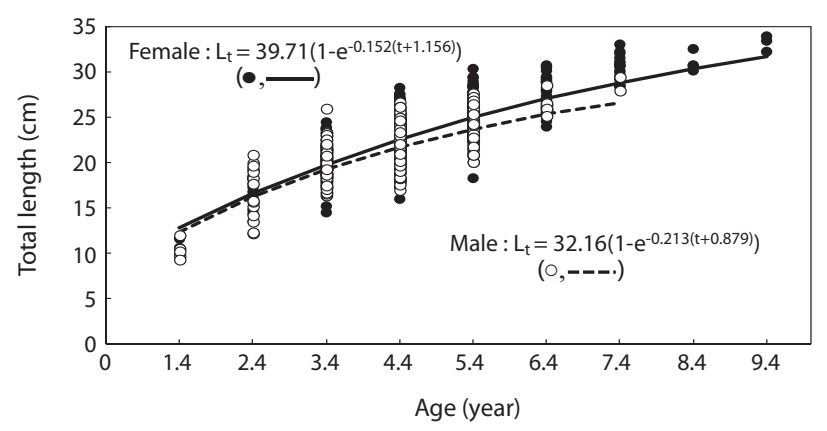

Fig. 7. The von Bertalanffy growth curves in total length estimated by a non-linear regression method of Blackfin flounder Glyptocephalus stelleri in the East Sea from January to December 2007.

$\mathrm{L}_{\mathrm{t}}=39.71\left(1-\exp ^{(-0.152(t+1.156))}\right)$ for females; $\mathrm{L}_{\mathrm{t}}=32.16(1-$ $\left.\exp ^{(-0.213(t+0.879))}\right)$ for males (Fig. 7).

\section{DISCUSSION}

The age of $G$. stelleri can be determined from the otoliths by observation of the sagittal plane, where opaque and translucent zones clearly alternate. The ages of flounders have been determined through observation of the sagittal sections of otoliths in various species such as Pleuronectes herzensteini (Choi et al., 1986), Verasper variegatus (Jeon et al., 1996), $P$. yokohamae (Park, 1997), C. pinetorum herzensteini (Choe et al., 1999), Cynoglossus joyneri (Baeck and Huh, 2004a), and Cynoglossus abbreviatus (Baeck and Huh, 2004b).

The growth structures of the left/right otoliths and the annulus mark formation position are different in some flounders such as $V$. variegatus (Jeon et al., 1996) and P. herzensteini (Choi et al., 1986), but the annuli in the otoliths of flounders are formed uniformly in the eye-side otoliths. Therefore, the eye-side otoliths were used in this study.

Our results indicate that annulus of G. stelleri formed once a year in September, delineated by the boundary between opaque and translucent zones. Lee (2008) reported otoliths formed opaque zones from April. Hashimoto (1953) reported that vertebral annuli form translucent zones (annual mark) during winter to spring. Ishida and Kitakata (1953) reported that otolith annuli form translucent zones from June to September, and that opaque zones are formed from March to May. Thus, the results of this study show differences in the formation of the annual mark.

The spawning period of $G$. stelleri has been reported to be April - June in the East Sea area of Korea (Cha et al, 2008), March - May in the Tottori, Japan (Tottori Prefecture Web Site, 2011), June - July in the Hokkaido, Japan (Hashimoto, 1953), April - July in Aomori, Japan (Hashimoto, 1953), May - September in Peter the Great Bay in Russia (Fadeev, 2005). Therefore, the spawning periods and formation of annual marks in G. stelleri show differences between sea areas.

We found that annulus formation occurred around September, with the first annulus formation at age 1.4 which is about 4 months after spawning period. Similar results have been reported for other flounders such as Eopsetta grigorjewi (Hwang et al., 1979), K. bicoloratus on the west sea coast (Jun and Im, 2004), and S. schlegeli inhabiting the Tongyeong marine ranch on the south coast of Korea (Park and Kang, 2007). Also, the annulus formation period of flounders in the East Sea was January - March for P. herzensteini (Choi et al., 1986), May for C. pinetorum herzensteini (Choe et al., 1999), and April - June for L. yokohamae (Kim et al., 1991), showing that the periods are different for each species, even when the environmental characteristics of their habitat are the same.

The growth of G. stelleri in Japanese and Russian sea is faster than that in the East Sea of Korea (Table 3). The maximum age of G. stelleri in Japanese sea is lower than that determined from the results of the present study, while the maximum age in Russian seas appears to be higher than that determined in the present study. Also, reviewing the actual size of samples, the maximum TL collected in this study was $38.1 \mathrm{~cm}$, but the TL of G. stelleri in Russian seas was recently reported to be 62 cm by Orlov and Tokranov (2007), which is markedly longer than the fish examined in this study.

There was no significant difference between males and females in the annual growth rate of $G$. stelleri up to age 2 $(P>0.05)$, but the growth rate of females was faster than that of males after age $3(P<0.05)$. Hashimoto (1953), Ishida and Kitakata (1953), and Tokranov (2008) reported similar results, with the growth rates of females being faster than those of

Table 3. Comparison of age, total length and location of Glyptocephalus stelleri reported by different authors

\begin{tabular}{llll}
\hline \multicolumn{1}{c}{ Authors } & \multicolumn{2}{c}{ Range of age and total length(cm) } & Male \\
\cline { 2 - 4 } & \multicolumn{1}{c}{ Female } & $1(10.45)-7(26.39)$ & Location \\
\hline This study & $1(10.72)-9(31.50)$ & $1(11.39)-3(22.16)$ & East Sea, Korea \\
Hashimoto (1953) & $1(11.23)-5(32.19)$ & $2(13.25)-6(26.08)$ & Hokkaido and Hachinohe, Japan \\
Ishida and Kitakata (1953) & $2(13.13)-8(34.23)$ & $5(22.30)-15(44.50)$ & Okhotsk, Russia \\
Tokranov (2008) & $6(24.80)-20(50.00)$ & $1(10.63)-6(21.55)$ & East Sea, Korea \\
Lee (2008) & $1(12.32)-7(27.78)$ & &
\end{tabular}


males at an older age. The oldest specimens in this study were a 9-years-old female and a 7-years-old male. The oldest individuals in other studies have been 8 and 6 in the G. stelleri samples from Hokkaido Ken, Japan (Ishida and Kitakata, 1953), 5 and 3 in samples from Hokkaido Sea and Aomori Prefecture, Japan (Hashimoto, 1953), and 20 and 15 in samples from Kamchatka in the Sea of Okhotsk (Tokranov, 2008) for females and males, respectively.

Geographic differences in the growth rates and longevities of $G$. stelleri are considered to be related not only to environmental factors, but also to fishing intensity. Catchs of $G$. stelleri in the East Sea have an increasing trend amounting to $54.9 \%$ of the total catches of the flounders (National Fisheries Research and Development Institute, 2010). High fishing intensity leads to the mean age of caught fish being reduced (Zhang, 1991). The low mean age of G. stelleri caught in the East Sea could indicate high fishing pressure. Intensive stock assessments and research on management plans are needed to rebuild the population of Korean flounders in the East Sea.

\section{Acknowledgments}

We are grateful to three anonymous reviewers. This study was funded by a grant from the National Fisheries Research and Development Institute, Korea (RP-2011-FR-020).

\section{References}

Baeck GW and Huh SH. 2004a. Age and growth of red tongue sole (Cynoglossus joyneri) in the Southern Sea of Korea. J Korean Fish Soc 37, 307-311.

Baeck GW and Huh SH. 2004b. Age and growth of three-lined tonguefish (Cvnoglossus abbreviatus) (Soleidae; Teleostei). J Korean Fish Soc 37, 51-56.

Cha HK, Kwon HC, Lee SI, Yang JH, Chang DS and Chun YY. 2008. Maturity and spawning of Korean flounder, Glytocephalus stelleri (Schmidt) in the East Sea of Korea. Korean J Ichthyol 20, 263-271.

Choe SH, Hur YH, Chun YY and Zhang CI. 1999. Growth and Maturity of pointedhead Flounder, Cleisthenes pinetorum herzensteini (Schmidt) in the East Sea. J Korean Soc Fish Res 2, 1-13.

Choi SH, Chun YY, Gong YG and Son SJ. 1986. Studies on the age, growth and maturity of the flounder Limanda herzensteini Jordan et Snyder in Yong-il Bay of the eastern sea of Korea. Bull Nat'1 Fish Res Dev Inst 39, 43-51.

Choi Y, Kim JH and Park JY. 2002. Marine Fishes of Korea. Kyo Hak Publ., Seoul, Korea.

Fadeev NS. 2005. Guide to Biology and Fisheries of Fishes of the North Pacific Ocean. TINRO-Center, Vladivostok, Russia.

Fedorov VV, Chereshnev IA, Nazarkin MV, Shestakov AV and Volobuev VV. 2003. Catalog of Marine and Freshwater Fishes of the Northern Part of the Sea of Okhotsk. Dalnauka, Vladivostok, Russia.
Hashimoto R. 1953. Studies on the age of Glyptocephalus stelleri (Schmidt). Bull Tohoku Reg Fish Res Lab, 2, 49-55.

Hayase S and Hamai I. 1974. Studies on feeding habits of three flatfishes, Cleisthenes pinetorum herzensteini (Schmidt), Hippoglossoides dubius (Schmidt) and Glypttocephalus stelleri (Schmidt). Bull Fac Fish Hokkaido Univ 25, 82-99.

Hwang BN, Choi SH and Hong ST. 1979. Biological study of flounder (Eopsetta grigorjewi Herzestein) in the south-western sea of Korea (II). Bull Nat'1 Fish Res Dev Inst 21, 23-33.

Ishida R and Kitakata M. 1953. Studies on the age determination of flatfishes in Hokkaido, Glyptocephalus stelleri (Schmidt). Bull Hokkaido Reg Fish Res Lab 8, 63-84.

Ivankova ZG. 1974. Fecundity and pattern of spawning in Glyptocephalus stelleri (Schmidt) from Peter the Great Bay. In studies on Fish Biology and Commercial Oceanography. Vol. 4. Kizevetter IV, ed/ TINRO, Vladivostok. pp. 118-121.

Jeon BS, Park BH, Jeon IK and Kang YJ. 1996. Age and growth of spotted halibut, Verasper variegatus. Korean J Ichthyol 8, 56-63.

Jun JC and Im YJ. 2004. Age and growth of stone flounder, Kareius bicoloratus, in western coastal waters of Korea. Korean J Ichthyol $16,173-180$

Kim YH, Kang YJ and Bae IJ. 1991. Age and growth of marbled sole Limanda yokohamae Günther Korean J Ichthyol 3, 130-139.

Lee JM. 2008. Age and growth of Korean flounder (Glyptocephalus stelleri) in the East Sea of Korea. MS Thesis, Pukyong National University, Busan, Korea.

Lee TW. 2011. Seasonal variation in species composition of demersal fish in the coastal water off Uljin and Hupo in the East Sea of Korea in 2002. Korean J Ichthyol 23, 187-197.

Matarese AC, Kendall AW Jr, Blood DM and Vinter MV. 1989. Laboratory Guide to Early Life History Stages of Northeast Pacific Fishes. NOAA, Technical Report NMFS No. 80, U. S. Department of Commerce, National Oceanic and Atmospheric Administration, National Marine Fisheries Service, Springfield, VA, US.

National Fisheries Research and Development Institute. 2004. Commercial Fishes of the Coastal and Offshore Waters in Korea. 2nd ed. Hangul Press Busan, Korea.

National Fisheries Research and Development Institute. 2010. Proceedings of the Symposium for Stock Rebuilding in the East Sea. East Sea Fisheries Research Institute Gangneung, 17 Jun 2010, KR.

Okiyama M. 1963. Larvae and young of the witch flounder, Glyptocephalus stelleri (Schmidt) at metamorphosis stages. Bull Jpn Sea Reg Fish Res Lab 11, 101-108.

Orlov AM and Tokranov AM. 2007. Distribution and some biological features of four poorly studied deep benthic flatfishes (Pleuronectiformes: Pleuronectidae) in the Northwestern Pacific Ocean. Raffles Bull Zool Suppl 14, 221-235.

Park HH, Jeong EC, Bae BS, Yang YS, Hwang SJ, Park JH, Kim YS, Lee SI and Choi SH. 2007. Fishing investigation and species composition of the catches caught by a bottom trawl in the deep East Sea. J Korean Soc Fish Technol 43, 183-191.

Park JS. 1997. Age and growth of the marbled sole, Pleuronectes yokohamae, in approaches to Kyongyolbiyolto of the Yellow Sea, Korea. Bull Korean Soc. Fish Technol 33, 85-89. 
Park KD and Kang YJ. 2007. Age and growth of black rockfish, Sebastes schlegeli, in the Tongyeong marine ranching area in Korea waters. Korean J Ichthyol 19, 35-43.

Pushchina OI. 2000. Specific features of feeding of the Glyptocephalus stelleri and Acanthopsetta nadeshnyi in the northwestern Sea of Japan. J Ichthyol 40, 247-252

Shvydkii GV and Vdovin AN. 2001. Seasonal distribution of the Korean flounder Glytocephalus stelleri in the northwestern part of the Sea of Japan. Oceanology 41, 565-569.

Tokranov AM. 2008. Specific features of distribution and some features of biology of Korean flounder Glyptocephalus stelleri (Pleuronectidae) in waters off Kamchatka in the Sea of Okhotsk. J Ichthyol 48, 759-769.
Tottori Prefecture Web Site. 2011. Glytocephalus stelleri [Internet]. Tottori Prefecture, Tottori, Accessed 8 Jun 2012, http://www.pref. tottori.lg.jp/dd.aspx?menuid=73961.

Von Bertalanffy L. 1938. A quantitative theory of organic growth (Inquiries on growth laws II). Hum Biol 10, 181-213.

Walford LA. 1946. A new graphic method of describing the growth of animals. Biol Bull 90, 141-147.

Yoon SC, Cha HK, Lee SI, Chang DS, Hwang SJ and Yang JH. 2008. Variations in species composition of demersal organisms caught by trawl survey in the East Sea. J Korean Soc Fish Technol 44, 323-344

Zhang CI. 1991. Fisheries Resource Ecology. Woosung Publ Co Seoul, Korea. 